\title{
Hamburgerlerin Bazı Kalite Özelliklerine Mercimek Püresi Illavesinin Etkisi
}

\author{
M.Murat HASBIOĞLU! A.Hamdi ERTAŞ²
}

Geliş Tarihi : 31.12.1997

\begin{abstract}
Özet : Mercimek (Lens culinaris L. Medik.) unu, ağırığının iki katı su ile sulandırılmış, 20. dakika kaynatılmış, soğutulduktan sonra hamburgerlerin üretiminde $\% \quad 0, \% 5, \% 10$ ve $\% 20$ oranında kullanılımış ve mercimek püresinin hamburgerlerin bazı kalite özelliklerine etkisi araştııılmıştır.

Mercimek pöresi ilavesi, hamburgerlerin $\mathrm{pH}$ değerini ve su tutma kapasitesini artırmış $(P<0,01)$, yağ oksidasyonunu, pişirme kaybını, büzülme oranını ve kalınlık artıșını azaltmıştır $(P<0,01)$. Duyusal olarak $\% 5$ mercimek püreli hamburgerıer kontrolden daha fazla beğenilmiştir. Yüzde 10 ve \% 20 mercimek püresi, hamburgerlerin renk, çiğneme hissi ve lezzet beğenilerini azaltmış ve $\% 20$ mercimek püreli hamburgerler en az beğenilen grup olmuştur.
\end{abstract}

Anahtar Kelimeler : Hamburger, mercimek püresi ilavesi, donmuş depolama, kalite özellikleri.

\section{Effect of Mashed Lentil (Lens culinaris L. Medik.) Addition on Some Quality Characteristics of Hamburgers}

\begin{abstract}
Lentil (Lens culinaris L. Medik.) flour was hyrated at a ratio of 2:1 (w/w) water to lentil flour and boiled for $20 \mathrm{~min}$. Mashed lentils were added at 5,10 and $20 \%$ to hamburgers and the effect of mashed lentil addition on some quality characteristics of hamburgers was investigated.

Mashed lentil addition increased $\mathrm{pH}$ and water holding capacity of hamburgers $(\mathrm{P}<0,01)$. Moreover, it decreased lipid oxidation, cooking loss, shrinkage and thickness $(P<0,01)$. Acceptability of hamburgers with $5 \%$ mashed lentil addition for color, chewing and flavor was higher than that of control. On the contrary, mashed lentil addition with $10 \%$ and $20 \%$ decreased the acceptability of sensorial characteristics.
\end{abstract}

Key Words : Hamburger, mashed lentil addition, frozen storage, quality characteristics.

\section{Giriş}

Kentlerde çalışan nüfusun artışı ve beslenme alışkanlıklarının değişmesi, kişilerin çabuk hazırlanan gıdalara yönelmesine neden olmuştur. Çeşitli köfteler, döner, lahmacun, etli pide gibi Türkiye'ye özgü çabuk hazırlanan ürünler arasına "hamburger" olarak isimlendirilen ürün de girmiş ve bu tip ürünler arasında önemli bir yer almıștır.

Bir köfte çeşidi olan hamburger, Türk Standartlarında (Anonim, 1992) "kasaplık hayvan gövde etlerinin tercihan kasaplık dana gövde etleri ve/veya kasaplık koyun gövde etlerinin, kasaplık kuzu gövde etlerinin kemik, tendon, fasia, kıkırdak, lenf yumrusu ve sinirleri ayrıldıktan sonra, yemeklik tuz, gerektiğinde iç yağı, böbrek yağı, kuyruk yağı, lezzet ve çeşni verici maddelerin bir veya birkaçı ile katkı maddeleri ilave edilip çekilmesi ve homojen hale gelinceye kadar karıştırılması ile elde edilen bir ürün" olarak tarif edilir.

Kıyma tipi et ürünlerinde bitkisel proteinlerin kullanımı, ürünün yapısına, besleyici değerine, lezzetine ve maliyetine etki etmektedir (Rakosky 1970, Turgut 1978). Bitkisel unlar, kıyma tipi ürünlere maliyeti düșürmek amacıla ucuz materyaller olarak ilave edilmesine rağmen, ürünün yağ ve kolestrol miktarını oransal olarak azaltması, üründe su ve yağ tutulmasını artırması dolayısıyla pişirme verimini artırması gibi önemli yararları sağlaması amacıyla da ilave edilmektedir (McWatters 1977. Shaner ve Baldwin 1979, Rhee ve Smith 1983 , Minerich ve ark. 1991). Ancak ilave edilen bitkisel unun miktarının artışı, hamburger tipi ürünün kendine özgü lezzetinin değişmesine ve beğenisinin azalmasına neden olmaktadır (McWatters 1977, Bowers ve Engler, 1975. Smith ve ark. 1976).

Bu konuda yapılan araştırmalar daha çok soya ürünleri ilavesinin etkisi üzerinde yoğunlaşmış ve köfte tipi et ürünlerine ilave edilen çeşitli soya ürünlerinin, köftelerin - hamburgerlerin bazı kalite özelliklerine olan etkileri araştırılmıştır (Judge ve ark. 1974, Bowers ve Engler 1975. Drake ve ark. 1975, Kotula ve ark. 1976, Smith ve ark. 1976, McWatters 1977, Shaner ve Baldwin 1979, Rhee ve Smith 1983, Berry ve ark. 1985, Padda ve ark. 1985. Patana ve Foegeding 1985, Kaya 1987, Kaya ve Gökalp 1990). Ayrıca pamuk tohumu unu (Rhee ve Smith 1984), vital buğday gluteni (Patana ve Foegeding 1985),

\footnotetext{
'Gıda Yüksek Mühendisi

${ }^{2}$ Ankara Üniv. Ziraat Fak. Gıda Mühendisliği Bölümü - ANKARA
} 
fasulye ve nohut unu (Moharram ve ark. 1987), pirinç unu (Minerich ve ark. 1991, Moharram ve ark. 1987), misır ruşeymi unu (Lin ve Zayas 1987, Reitmeier ve Prusa 1991) köfte tipi ürünlerin formúlasyonlarında denenmiş ve ürünün bazı kalite özelliklerine olan etkileri araştırılmıştır.

Bu çalışmada $\% 0, \% 5, \% 10$ ve $\% 20$ mercimek püresi içeren hamburgerler hazırlanmış ve 60 gün süre ile $-20 \pm 2^{\circ} \mathrm{C}$ 'de depolanmışlardır. Mercimek püresi ilavesinin ve depolama süresinin hamburgerlerin bazı özellikleri üzerine olan etkisi araştırılmıştır.

\section{Materyal ve Yöntem}

Hamburgerlerin yapılmasında $\% 70$ sığır eti, $\% 20$ yag̉, $\% 7$ soğan, $\% 2$ tuz, $\% 0,5$ karabiber ve $\% 0,5$ kırmızıbiber kullanılmıştır. Bu formül, kontrol grup olarak kabul edilmiş ve mercimekli gruplarda, ilave edilen püre haldeki mercimek miktarları ( $\% 5, \% 10, \% 20)$, kıyma miktarından düşülmüştür. Kırmızı mercimek (Lens culinaris L. Medik.) unu (nem \%11.6, protein \%23.7, yağ $\% 1,3$ ve kül $\% 5,6$ olarak saptanmıştır), ağırlığının iki katı içme suyu ile 20 dakika haşlanmış ve püre hale getirildikten ve soğutulduktan sonra kullanılmıştır.

Görünen bag̃ doku ve yağından temizlenen parça etler, delik çapı $10 \mathrm{~mm}$ olan ayna kullanılarak kıyma makinasından geçirilmiş ve kuşbaşı hale getirilmiştir. Yağ da aynı şekilde hazırlanmıştır. Her grup için hesaplanan et, yağ, mercimek püresi, soğan (blenderde parçalanmış halde), tuz, karabiber ve kırmızibiber paslanmaz çelik küvet içerisinde karıştırılmış ve delik çapı $3 \mathrm{~mm}$ olan aynı kullanılarak kıyma makinasından iki kez çekilmiştir. Böylece hazırlanan hamburger hamuru, 50'şer gram tartılarak, $5 \mathrm{~mm}$ kalınlığında ve $95 \mathrm{~mm}$ çapında özel olarak hazırlanan kalıplarda şekillendirilmiş ve paslanmaz çelik tavalara dizilerek deep-freeze'de $-25^{\circ} \mathrm{C}$ 'de 24 saat dondurulmuştur. Her grup hamburger, aralarında selofan kağıt olacak şekilde beşerli halde alüminyum folyo ile paketlenmiş ve $-20 \pm 2{ }^{\circ} C^{\prime}$ deki deep-freeze'de depolanmışlardır.

Hamburgerlerin nem, protein ( $\%$ azot $\times 6,25)$, yağ ve kül miktarları Anonim'e (1984), pH değeri Lees'e (1975), TBA değeri Tarladgis ve ark.'na (1960), su tutma kapasitesi (STK) Zayas ve Lin'e (1988) göre saptanmıştır. Su tutma kapasitesinin hesaplanmasında, STK $=1$ - (et yayılma alan / su yayılma alanı) formülü kullanılmıştır. Burada, hesaplanan STK değeri küçüldükçe, ürünün sızdırdığı su azalmaktadır. Pişirme kaybı, büzülme ve kalınlık artışı, hamburgerlerin bir yüzũnün iki dakika, ikinci yüzünün bir dakika süre ile yağsız olarak kızartıldıktan ve oda sıcaklığına soğuduktan sonra aşağıdaki formüller kullanilarak saptanmıştır (Berry 1993).

Pişirme kaybı ( \%) = [(pişirme öncesi ağırlık-pişirme sonrası ağırlık) / pişirme öncesi ağırlık] $\times 100$

\section{Büzülme $(\%)=[($ pişirme öncesi alan-pişirme sonrası alan) / pişirme öncesi alan] x 100}

Kalınlık artışı $(\%)=[($ pişirme sonrası kalınlık-pişirme öncesi kalınlık) / pişirme öncesi kalınlık] x 100

Kalınlık artışı, hamburgerin birbirine dik hayali iki çapı üzerinde kenardan $1,5 \mathrm{~cm}$ uzaktaki dört noktada ve merkezde yapılan ölçümlerin ortalaması sonucu belirlenmiştir.

Duyusal değerlendirme, hamburgerlerin bir yüzünün iki dakika, ikinci yüzünün bir dakika süre ile yağsız olarak kızartıldıktan sonra, renk, çiğneme hissi, lezzet ve genel beğeni yönlerinden yedi panelist tarafından dokuz puan üzerinden yapılmıştır.

Çalışma, tesadüf parselleri deneme düzeninde iki tekerrürlü olarak planlanmış ve belirlenen analizler, başlangıç, depolamanın 30 . ve 60 . gününde yapılmıştır. Nem, protein, yağ ve kül miktarları ile $\mathrm{pH}$ değeri, TBA değeri ve su tutma kapasitesinin belirlenmesinde, her grupdan tesadüfi dört hamburger alınmıș, ikili olarak birbiriyle karıştırılmış ve analizler dört paralel olarak yapılmıştır. Pişirme kaybı, büzülme ve kalınlık artışı, her grupdan tesadüfi alınan üç hamburgerde (üç paralel) belirlenmiştir.

pH değeri, TBA değeri, su tutma kapasitesi, pişirme kaybı, büzülme oranı ve kalınlık artışı sonuçları iki faktörlü (mercimek püresi miktarı ve depolama süresi) faktöriyel düzende, duyusal değerlendirme sonuçları basit tekrarlanan ölçümlü deneme düzeninde varyans analizi ve Duncan çoklu karşılaşma testiyle istatistiksel olarak kontrol edilmiştir.

\section{Bulgular ve Tartışma}

Değişik miktarda mercimek püresi ilave edilerek üretilen hamburgerlerde nem, protein, yağ ve kül miktarları, ürünü karakterize etmek amacıyla belirlenmiş ve Çizelge 1'de verilmiştir.

Hamburgerlerin $\mathrm{pH}$ değerlerine gerek mercimek püresi ilavesi gerekse depolama süresi etkili olmuş $(P<0,01)$ ve mercimek püresi miktarının artışı ve depolama süresinin uzaması $\mathrm{pH}$ değerinin artmasına neden olmuştur. Ancak pH değerindeki bu artışın, kontrol grup ile $\% 5$ mercimek püreli grup arasmda ve $\% 5$ mercimek püreli grup ile $\% 10$ mercimek püreli grup arasında önemsiz, diğer gruplar arasında önemli olduğu görülmüştür. Ayrica hamburgerlerin başlangıçtaki $\mathrm{pH}$ değerleri ile depolamanın 30 . günündeki ve 60 , günündeki $\mathrm{pH}$ değerleri arasındaki fark önemli $(\mathrm{P}<0,01)$, depolamanin 30. günündeki $\mathrm{pH}$ değerleri ile 60 . günündeki $\mathrm{pH}$ değeri arasındaki fark önemsiz bulunmuştur (Çizelge 2). 
Çizelge 1. Hamburgerlerin nem, protein, yağ ve kül miktarları (\%)

\begin{tabular}{lcccc}
\hline & Nem & Protein & Yağ & Kül \\
\hline Kontrol & 59,61 & 16,32 & 18,96 & 2,67 \\
$\% 5$ Mercimek püreli & 59,72 & 15,07 & 18,62 & 2,71 \\
$\%$ 10 Mercimek püreli & 60,56 & 14,98 & 17,53 & 2,88 \\
$\%$ 20 Mercimek püreli & 61,42 & 13,27 & 17,98 & 2,94 \\
\hline
\end{tabular}

Çizelge 2. Hamburgerlerin $\mathrm{pH}$ değerleri

\begin{tabular}{lcccc}
\hline & & Depolama süresi & \\
\cline { 2 - 4 } & Başlangiç & 30 .gün & 60 . gün & $\bar{x}$ \\
\hline \multirow{2}{*}{ Kontrol } & 5,64 & 5,75 & 5,78 & $5,72^{\mathrm{C}}$ \\
$\%$ 5 Mercimek püreli & 5,69 & 5,82 & 5,84 & $5,78^{\text {be }}$ \\
$\%$ 10 Mercimek püreli & 5,75 & 5,85 & 5,88 & $5,82^{\mathrm{b}}$ \\
$\%$ 20 Mercimek püreli & 5,96 & 5,92 & 5,95 & $5,94^{\mathrm{a}}$ \\
$\bar{x}$ & $5,76^{\mathrm{B}}$ & $5,84^{\mathrm{A}}$ & $5,86^{\mathrm{A}}$ & \\
\hline
\end{tabular}

a,b,c ve A,B : Değişik harfleri taşıyan gruplar arasındaki fark önemlidir $(P<0,01)$

Mercimek püresinin hamburgerlerin $\mathrm{pH}$ 'sının artışına neden olduğu gibi, yağsız soya ununun (Keeton ve Melton 1978, Padda ve ark. 1985, Kaya 1987, Kaya ve Gökalp 1990) ve pamuk tohumu ununun da (Rhee ve ark. 1985) köfte tipi et ürünlerinin $\mathrm{pH}$ 'sını artırdığı, buna karşın pirinç ununun (Minerich ve ark. 1991) bu tip ürünlerin pH'sına etkili olmadığı belirtilmektedir.

Hamburgerlerin yağının oksidasyonu dolayısıyla TBA değeri üzerine gerek mercimek püresi ilavesi gerekse depolama süresi etkili olmuştur $(P<0,01)$. Hamburgerlere mercimek püresi ilavesi, yağın oksidasyonunu azaltarak, olumlu yönde etki ederken, depolama süresinin uzaması yağın oksidasyonunu artırmıştır. Mercimek püresinin TBA değeri üzerine olan etkisi, $\% 5$ ile $\% 10$ mercimek püreli hamburgerler arasında ve $\% 10$ ile $\% 20$ mercimek püreli hamburgerler arasında önemsiz, diğer gruplar arasında önemli $(P<0,01)$ olmuştur. Depolama süresinin TBA değeri üzerine olan etkisi, başlangıç ile 30 . gün değerleri arasında önemsiz, 60. gün değerleri arasında önemli $(P<0,01)$ olmuştur (Çizelge 3 ).

Köfte tipi ürünlerdeki yağ oksidasyonunu, yağsız soya ununun (Kotula ve ark. 1976, Ray ve ark. 1981), pamuk tohumu ununun (Rhee ve ark. 1985) ve pirinç ununun (Minerich ve ark. 1991) da engellediği ifade edilirken, Kaya (1987) ile Kaya ve Gökalp (1990) hamburgerlerdeki ve köftelerdeki yağ oksidasyonunu yağsız soya ununun hızlandırdığını belirtmektedirler.

Hamburgerlere mercimek püresi ilavesi arttıkça, daha düşük su tutma kapasitesi değerleri elde edilmiş. yani mercimek püresi ilavesi, hamburgerlerin su tutma kapasitesini artırmıştır. Su tutma kapasitesindeki artış, kontrol ile $\% 5$ mercimek püresi ilaveli grup arasında ve $\% 10$ ile $\% 20$ mercimek püresi ilaveli grup arasında önemsiz diğer gruplar arasında önemli $(P<0,01)$ olarak saptanmıştır (Çizelge 4). Mercimek püresi ilaveli hamburgerlerin su tutma kapasiteleri üzerine depolama süresinin etkisinin önemli olmadığı $(P>0,05)$ görülmüştür.

Minerich ve ark. (1991) köfteye pirinç unu ilavesinin; Padda ve ark. (1985) ise soya unu ilavesinin köftenin suyunu ve yağını alıkoyma özelliğini önemli derecede artırdığını belirtmektedirler.

Kontrol grubu hamburgerlerde başlangıçta \%34.4 olarak belirlenen pişirme kaybı, hamburgerlere mercimek püresi ilavesiyle azalmış ve $\% 5, \% 10$ ve $\% 20$ mercimek püreli hamburgerlerde sırasıyla $\% 29,1, \% 27,0$ ve $\% 25,0$ olarak saptanmıştır. Hamburgerlere her düzeyde mercimek püresi ilavesi pişirme kaybını azaltırken $(P<0,01)$, pişirme kaybı üzerine depolama süresinin etkisinin olmadığı $(P>0,05)$ görülmüştür (Çizelge 5$)$.

Çizelge 3. Hamburgerlerin TBA değerleri (mg MA/kg)

\begin{tabular}{lcccc}
\hline & & Depolama süresi & \\
\cline { 2 - 4 } & Başlangı̨̧ & 30 gün & 60. gün & $1,30^{\mathrm{a}}$ \\
Kontrol & 0,93 & 1,12 & 1,86 & $0,93^{\mathrm{b}}$ \\
$\%$ 5 Mercimek püreli & 0,71 & 0,85 & 1,23 & $0,78^{\mathrm{bc}}$ \\
$\%$ 10 Mercimek püreli & 0,69 & 0,71 & 0,94 & $0,67^{\mathrm{C}}$ \\
$\%$ 20 Mercimek püreli & 0,58 & 0,63 & 0,79 & \\
$\bar{x}$ & $0,73^{\mathrm{B}}$ & $0,83^{\mathrm{B}}$ & $1,21^{\mathrm{A}}$ & \\
\hline
\end{tabular}

\footnotetext{
a,b,c ve A.B : Değişik harfleri taşıyan gruplar arasındaki fark önemlidir $(P<0,01)$
} 
Çizelge 4. Hamburgerlerin su tutma kapasiteleri

\begin{tabular}{lcccc}
\hline & & Depolama süresi & & \\
\cline { 2 - 4 } & Başlangıç & 30. gün & 60.gün & $\bar{x}$ \\
\hline Kontrol & 0,52 & 0,53 & 0,53 & $0,53^{\mathrm{a}}$ \\
$\%$ 5 Mercimek püreli & 0,47 & 0,49 & 0,50 & $0,49^{\mathrm{a}}$ \\
$\%$ 10 Mercimek püreli & 0,37 & 0,38 & 0,41 & $0,39^{\mathrm{b}}$ \\
$\%$ 20 Mercimek püreli & 0,31 & 0,32 & 0,35 & $0,33^{\mathrm{b}}$ \\
\hline
\end{tabular}

a.b : Değişik harfleri taşıyan gruplar arasındaki fark önemlidir $(P<0,01)$

Çizelge 5. Hamburgerlerin pişirme kayıpları (\%)

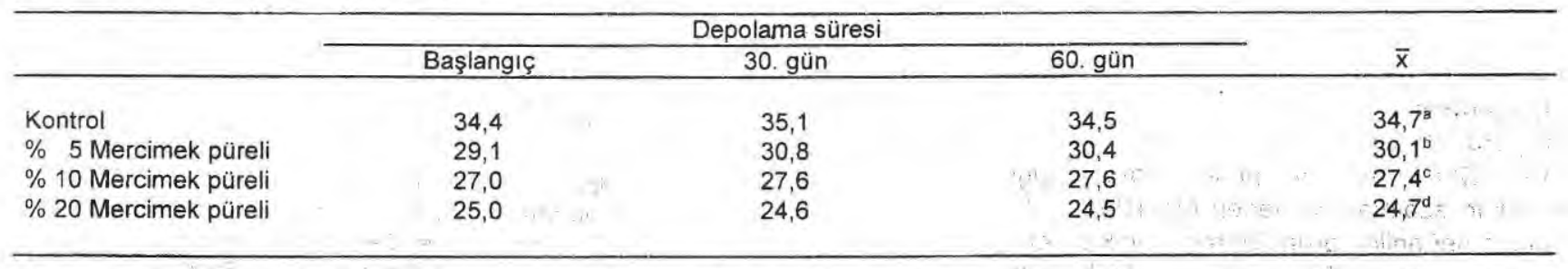

a.b.c.d : Değişik harfleri taşıyan gruplar arasındaki fark önemlidir $(P<0,01)$

Padda ve ark. (1985), köftelere \%20 soya unu ilavesinin köftenin pişirme verimini \%3,9 artırdığını; Berry ve ark. (1985), \%35,7 soya unu ilavesinin köftelerin pişırme verimini \%8 artırdığını; Kaya (1987), \%30 soya unu ilavesinin hamburgerin pişirme kaybını $\% 7,7$ azalttığını; Reitmeier ve Prusa (1991), \%5 mısır rüşeymi unu ilavesinin domuz eti kıymalarının pişirme kaybını $\% 9$ azalttığını; Minerich ve ark. (1991), \%30 pirinç unu ilavesinin köftenin pişirme verimini $\% 10$ artırdığını ve bu artışın ilave edilen pirinç ununun köftenin suyunu ve yağını alıkoyma özelliğini artırmasının bir sonucu olduğunu belirtmektedirler.

Hamburgerlerin pişirilmesi sonucu ortaya çıkan büzülme oranına, mercimek püresi ilavesi etkili olurken $(P<0,01)$, depolama süresinin etkili olmadığı $(P>0,05)$ görülmüştür. Mercimek püresi ilavesi arttıkça, hamburgerlerin büzülme oranı azalmış dolayısıyla daha geniş yüzey alanına sahip ürün elde edilmiş, ancak $\% 5$ mercimek püreli grup ile $\% 10$ mercimek püreli grup arasındaki fark önemli olmamıştır (Çizelge 6).
Judge ve ark. (1974), Berry ve ark. (1985) ve Padda ve ark. (1985) da soya unu ilavesinin köftelerin büzülme oranını önemli derecede azalttığını belirtmektedirler.

Hamburgerlere mercimek püresi ilavesi, hamburgerlerin büzülme oranını azaltırken, buna bağlı olarak hamburgerlerin kalınlık artışının da azalmasına neden olmuştur. Nitekim ortalama olarak kontrol grupda $\% 13,03$ olarak belirlenen kalınlık artışı, $\% 5, \% 10$ ve $\% 20$ mercimek püreli hamburgerlerde sırasıyla $\% 9,89, \% 7,02$ ve $\% 4,46$ olarak belirlenmiş ve gruplar arası fark önemli olmuştur $(P<0,01)$ (Çizelge 7$)$. Ancak, hamburgerlerin kalınlık artışı üzerine depolama süresinin etkisinin olmadığı görülmüştür $(P>0,05)$.

Değişik oranlarda mercimek püresi içeren hamburgerlerin duyusal değerlendirme sonuçları Çizelge 8 'de verilmiştir. Hamburgerlere $\% 5$ mercimek . püresi ilavesi, görsel olarak hamburgerlerin renginin daha fazla beğenilmesine neden olurken $(P<0,01)$, kontrol grup ile \%10 mercimek püreli grup arasında fark olmadığı görülmüş ve $\% 20$ mercimek püresi ilavesi renk beğenisinin azalmasına neden olmuştur $(P<0,01)$.

Çizelge 6. Hamburgerlerin büzülme oranları (\%)

\begin{tabular}{|c|c|c|c|c|c|c|}
\hline & & \multicolumn{3}{|c|}{ Depolama súresi } & \multirow[b]{2}{*}{$\bar{x}$} & \\
\hline & & Bașlangıç & 30. gün & 60. gün & & . \\
\hline Kontrol & & 385 & 395 & 416 & $399^{a}$ & \\
\hline$\% \quad 5$ Mercimek püreli & & 33,5 & 34.0 & 34,5 & $34,0^{\mathrm{b}}$ & \\
\hline$\% 10$ Mercimek püreli & & 32,5 & 32,8 & 34,1 & $33,1^{b}$ & \\
\hline$\% 20$ Mercimek püreli & . & 30,0 & 30,3 & 30,3 & $30,2^{\mathrm{c}}$ & \\
\hline
\end{tabular}

a,b.c : Değişik harfleri taşıyan gruplar arasındaki fark önemlidir $(P<0,01)$ 
Çizelge 7. Hamburgerierin kalınlık artışı (\%)

\begin{tabular}{|c|c|c|c|c|}
\hline & \multicolumn{3}{|c|}{ Depolama süresi } & \multirow[b]{2}{*}{$\bar{x}$} \\
\hline & Başlangıç, & 30. gün & 60. gün & \\
\hline Kontrol & 12,45 & 13,00 & 13,65 & $13,03^{\mathrm{a}}$ \\
\hline$\% 5$ Mercimek püreli & 9,45 & 9,87 & 10,35 & $9,89^{b}$ \\
\hline \% 10 Mercimek püreli & 6,45 & 6,90 & 7,70 & $7,02^{\circ}$ \\
\hline$\% 20$ Mercimek püreli & 4,30 & 4.45 & 4,63 & $4,46^{d}$ \\
\hline
\end{tabular}

t.b,c, d : Değişik harfleri taşıyan gruplar arasındaki fark önemlidir $(P<0,01)$

Çizelge 8. Değişik oranlarda mercimek püreli hamburgerlerin duyusal beğeni puanları *

\begin{tabular}{lcccc}
\hline & Renk & Çiğneme hissi & Lezzet & Genel beğeni \\
\hline Kontrol & $7,15^{\mathrm{b}}$ & $7,08^{\mathrm{a}}$ & $7,22^{\mathrm{b}}$ & $7,32^{\mathrm{a}}$ \\
$\% 5$ Mercimek püreli & $7,71^{\mathrm{a}}$ & $7,43^{\mathrm{a}}$ & $7,75^{\mathrm{a}}$ & $7,68^{\mathrm{a}}$ \\
$\% 10$ Mercimek püreli & $6,89^{\mathrm{b}}$ & $6,54^{\mathrm{b}}$ & $6,50^{\mathrm{b}}$ & $6,55^{\mathrm{b}}$ \\
$\%$ 20 Mercimek püreli & $5,82^{\circ}$ & $5,64^{\circ}$ & $5,34^{\mathrm{a}}$ & $5,57^{\mathrm{a}}$ \\
\hline
\end{tabular}

* 8,1-9: Çok iyi; 7,1-8: Iyí; 6,1-7: Orta; $\quad$ 5,1-6: Kabul edilebilir; $\quad$ 5'in altı: Kötü

a.b.c,d : Değişik harfleri taşıyan gruplar arasındaki fark önemlidir $(P<0,01)$

Hamburgerlere $\% 5$ mercimek püresi ilavesi, hamburgerlerin çiğneme hissi beğenisini artırmış, ancak kontrol grup ile arasındaki fark önemli olmamıştır. Yüzde 10 ve $\% 20$ mercimek püresi ilavesi çiğneme hissi beğenisinin azalmasına neden olmuştur $(P<0,01)$. Lezzet yönünden beğenilen grup $\% 5$ mercimek püreli grup olmuş, mercimek püresi miktarının daha fazla artması lezzet beğenisinin azalmasına neden olmuştur $(P<0,01)$. Ayrıca, $\% 20$ mercimek ilaveli hamburgerlerde mercimek tadının ve kokusunun bariz bir şekilde hissedildiği panelistlerce ifade edilmiştir. Genel beğeni yönünden de $\% 5$ mercimek püreli hamburgerler en yüksek puanı almış, ancak kontrol grup ile arasındaki farkın önemli olmadığı görülmüştür. Mercimek püresi miktarının daha fazla artışı genel beğeniyi azaltmıştır $(P<0,01)$.

Sonuç olarak, hamburgerlere mercimek püresi ilavesinin, hamburgerlerin protein miktarını azalttığı, $\mathrm{pH}$ değerini yükselttiği ve yağ oksidasyonunu engellediği saptanmıştır. Hamburgerlere mercimek püresi ilavesi, ürünün su tutma kapasitesini artırmış dolayısıyla pişirme kaybını azaltmıştır. Mercimek püresi ilavesi, pişirme sonrası büzülme oranını ve kalınlık artışını azaltmış, dolayısıyla daha geniş yüzey alanına sahip ürün elde edilmesine neden olmuştur. Duyusal olarak, \%5 mercimek püreli hamburgerler beğenilen grup olmuş ve kontrol grup ile birlikte "iyi" olarak, \%10 mercimek püreli hamburgerler "orta" olarak ve $\% 20$ mercimek püreli hamburgerler "kabul edilebilir" olarak değerlendirilmiştir.

\section{Kaynaklar}

Anonim, 1984. Official Methods of Food Analysis. 14 th Ed. Association of Official Analytical Chemists. Washington. D.C.

Anonim, 1992. Türk Standartları, TS 10580. Köfte-Hamburger Köfte-Pişmemiş. Türk Standartları Enstitüsü, Ankara.
Berry, B.W. 1993. Fat level and freezing temperature affect sensory, shear, cooking and compositional properties of ground beef patties. J.Food Sci., 58, 34-37.

Berry, B.W., Leddy, K.F., Bodwell, C.E. 1985. Sensory characteristics, shear values and cooking properties of ground beef patties extended with iron-and zincfortified soy isolate, concentrate of flour. Food Sci., 50 , 1556-1559.

Bowers, J.A., Engler, P. 1975 Freshly cooked and cooked, frozen reheated beef and beef-soy patties. J.Food Sci., $40,624-625$.

Drake, S.R., Hinnergardt, L.C., Kluter, R.A., Prell, P.A. 1975. Beef patties. The effect of textured soy protein and fat levels on quality and acceptability. J.Food Sci., 40, 1065-1067.

Judge, M.D., Haugh, C.G., Zachariah, G.L., Parmelee, C.E., Pyle, R.L. 1974. Soya additives in beef patties. J.Food Sci., 39, 137-139.

Kaya M. 1987. Yağsız Soya Ununun Hamburger Tipi Et Ürünlerine Katılabilme Imkanian Üzerine Araştırmalar. Yüksek Lisans Tezi, Atatürk Üniv. Ziraat Fak., Erzurum.

Kaya, M. Gökalp, H.Y. 1990. Einfluls von textruertem Sojaprotein auf die Eigenschaften von Köfte. Fleischwirtsch., 70, 646-649.

Keeton, J.T., Melton, C.C. 1978. Factors accociated with microbial growth ground beef extended with varying levels of textured soy protein. J. Food Sci., 43, 11251129.

Kotula, A.W., Twigg, G.G., Young, E.P. 1976. Evaluation of beef patties containing soy protein during 12 -month frozen storage J.Food Sci., 41, 1142-1147.

Lees, R. 1975. Food Analysis. Analitical and Quality Control Methods for Manufacturer and Buyer. $3^{\text {rd }}$ Ed.. Leonard Hill Book, London. 
Lin, C.S., Zayas, J.F. 1987. Influence of corn germ protein on yield and quality characteristics of comminuted meat. products in a model system. J.Food. Sci., 52, 545-548.

McWaters, K.H. 1977. Performance of defatted peanut, soybean and field pea meals as extenders in ground beef patties. J.Food Sci., 42, 1492-1496.

Minerich, P.L., Addis, P.B, Epley, R.J. Bingham, C. 1991 Properties of wild rice/ground beef-mixtures. J.Food Sci., 56, 1154-1157.

Moharram, Y.G., Hamza, M.A., Aman, M.B., El-Akary, M.D. 1987 Technology and characteristics of beef burger containing plant substitutes. Food Chem., 26, 189-200

Padda, G.S., Kesava, R.V., Keshri, R.C., Sharma, N., Sharma B.D. 1985. Studies on physico-chemical and organoleptic properties of ham patties extended with texturised soy proteins. J.Food Sci. and Techn., 22, 362365.

Patana, A.G., Foegeding, E.A. 1985. Rheological and stability transtions in meat butters containing soy protein concentrate and vital wheat gluten. J.Food Sci., 50, 160164.

Rakosky, J.Jr. 1970. Soy products for the meat industry. J.Agr. Food Chem., 18, 1005-1009.

Ray, F.K., Parrett, N.A., Van Stavern, B.D., Ockerman, H.W. 1981. Effect of soy level and storage time on the quality. characteristics of ground beef patties. J.Food Sci. 46, 1662-1665.

Reitmeier, C.A., Prusa, K.J. 1991. Composition, cooking loss, color and compression of ground pork with dry-and wet-milled corn germ meals. Food Sci., 56, 216-219.
Rhee, K.S., Smith, G.C. 1983. Effect of cooking on cholesterol content of patties containing different amounts of beef, textured soy protein and fat. Food Sci., 48, 268-269.

Rhee, K.S., Smith, G.C. 1984. Effect of .sodium tripolyphosphate and ascorbic acid added with glandless cottonseed flour to ground beef. J. Food Prot., 47, 182-188.

Rhee, K.S., Vanderzant, C., Keeton, J.T., Ehlers, J.G., Leu, R. 1985. Microbiological and shelf-life properties of ground beet containing glandless cotton seed flour. J.Food Sci., 50, 1388-1391.

Shaner, K.M., Baldwin, R.E. 1979. Sensory propeties, proximate analysis and cooking losses of meat loaves extended with chich-pea meal on textured soy protein. J.Food Sci., 44, 1191-1194.

Smith, G.C., Marshall, W.H., Carpenter, Z.L., Branson, R.E., Meinke, W.W. 1976. Textured soy proteins for use in blended ground beef patties. J.Food Sci., 41, 1148-1152.

Tarladgis, B.G., Watts, B.M., Younathan, M.T., Dugan, J.L. 1960. A distillation method for quantitative determination of malonaldehyde in rancid foods. J.Amer. Oil Chem. Soc., $37,44-48$.

Turgut, H. 1978. Et ürünleri sanayiinde ürün kalitesini yükseltmek için kullanılan çeşitli katkı maddelerinin genel reaksiyonları, etkileri ve durumları. Gıda, 3, 89-93.

Zayas, J.F., Lin, C.S. 1988. Quality characteristics of frankfurters containing corn germ protein. J.Food Sci., $53,1587-1596$. 


\section{ANKARA ÜNIVERSITESİ ZIRAAT FAKÜLTESI TARIM BILIMLERİ DERGISİ YAYIN İLKELERI}

1. Dergide tarım bilimileri alanında yapılmış orijinal araştırmalar yayınlanır.

2. Dergide yayınlanacak eserler Türkçe,Íngilizce,Almanca ya da Fransızca dillerinden birinde yazılabilir.

3. Dergiye gelen eserlerin basımı öncesinde hakem görüşü alını. Yayın komisyonuna gönderilen makalelerin dergide yayınlanabilmesi için Editörler Kurulunca (yayın komisyonu) bilimsel içerik ve şekil bakımından uygun görülmesi ve hakemler tarafindan kabul edilmesi gerekir.Yayınlanması uygun bulunmayan eserler yazarına/yazarlarına geri gönderilir.

4. Dergide yayınlanacak eserin daha önce hiçbir yayın organında yayınlanmamı̧ ya da yayın hakkının verilmemiş olması gerekir.

5. Yayınlanması istenen eser dergiye; Microsoft Word Windows programında, Arial yazı karakterinde yazılarak; disketiyle birlikte, 1 bilgisayar Ç,ktısı, 2 fotokopi olmak üzere toplam 3 nüsha gönderilir.

6. Dergide yayınlanan eserin yazarına/yazarlarına 5 (beş) adet ücretsiz ayrı baskı verilir.Yazar/ yazarlar isterlerse baskıdan önce haber vermek koşuluyla ücreti karşılı̆̆ı daha fazla ayrı baskı yaptırabilirler.

7. Yazar soyadlarının son harfi üzerine rakam koyularak adresleri ilk sayfanın alında dipnot olarak verilir.

8. Yapılan çalışma bir kurum/kuruluş tarafından desteklenmiş ya da doktora/yüksek lisans tezinden hazırlanmış ise, bu durum ilk sayfanın altında dipnot olarak verilir.

9. Dergiye gönderilecek eser, ÖZET, ABSTRACT, GIRIŞ, MATERYAL ve YÖNTEM, BULGULAR ve TARTIŞMA, SONUÇ,TEŞEKKÜR (gerekirse), KAYNAKLAR şeklinde düzenlenir.

10. Dergiye gönderilecek eser, A4 normunda birinci hamur kağıda, 170×250 mm'lik alanı kapsayacak şekilde hazırlanmalı ve 8 sayfayı geçmemelidir.

11. Eser hangi dilde yazılırsa yazılsın, Türkçe özet ve İngilizce abstract içermeli, özetlere aym dilde başlık koyulmah ve 200 'er kelimeyi geçmemelidir. Özetler, $15 \mathrm{~cm}$ 'lik tek sütun halinde 8 punto ve 1 aralık ile yazılmalıdır.

12. Metin, $8 \mathrm{~cm}$ 'lik iki sütun halinde, 9 punto ve 1 aralık ile yazılmalıdır. Şekiller, grafikler, fotoğraflar ve benzerleri "Şekil", sayısal değerler ise "Çizelge" olarak belirtilir ve metin içerisine yerleştirilir.Şekil ve çizelgelerin eni 7,5 cm ya da $15,5 \mathrm{~cm}$ 'yi geçmemelidir. Şekil, Çizelge, dipnot ve kaynaklar da kullanılan harf büyüklüğü 8 punto olmalıdır.

13. Eserde yararlanılan kaynaklara ilişkin yazım "yazar ve yıl" yöntemine göre yapılır. Ü̧ ya da daha fazla yazarın kaynağı ifade edilmek istenirse "ve ark." kısaltması kullanılır, "kaynaklar" bölümünde tüm yazarlar belirtilir.

14. Yazarın/yazarların yaptığı sözlü görüşmeler ve yayınlanmış eserlere ait bildirimler, ilgili cümlenin son kelimesinin üzerine koyulacak rakam ile o sayfanın altında dipnot olarak belirtilir.

15. Kaynaklar listesi ilk yazarın soyadına göre alfabetik olarak düzenlenir ve numaralama yapılmaz. Yararlanılan kaynak;

Dergiden alınmışsa:

Yetişmeyen, A., N. Arıöz, 1995. Farklı koyulaştırma oranı ve kurutma sıcaklığında elde edilen yayıkaltı tozunun kalite kriterlerinin belirlenmesi. Gida, 20(2)117-122

Kitaptan alınmıșsa:

Düzgüneş, O., T. Kesici, O.Kavuncu ve F. Gürbüz, 1987. Araştırma ve Deneme Metodlan (İstatistik Metodları-II). Ankara Üniv.Zir.Fak. Yay. 1021, Ankara, 381 s.

Kitabın bir bölümünden alınmışsa:

Fıratlı, Ç. 1993. Arı Yetiştirme. "Ed. M.Ertuğrul, Hayvan Yetiştirme (yetiştiricilik)", s. 239-270, Ankara.

Yazarı bilinmeyen bir kaynaksa:

Anonim, 1993. Tarım İstatikleri Özeti 1991. T.C. Başbakanlık Devlet İstatistik Enstitüsü, Yayın No: 1579, Ankara.

16. Son düzeltme için yazarına/ yazarlarına gönderilen esere, ekleme ya da çıkarma yapılamaz.

17. İşlemi tamamlanan eserler geliş tarihi esas alınarak yayınlanır.

18. Bir yazarın, aynı sayıda ilk isim olarak en çok 2 (iki), ikinci ve dığer isim sıralamasında olmak üzere toplam 3 (üç) eseri basılabilir.

19. Eserin tüm sorumluluğu yazar/yazarlarına aittir.

20. Baskıya hazırlama, hakem ücreti ve posta giderleri eser sahibinden alınır. 